\title{
Finest frugt - om 'den Vartou Kjællingepræst': En guide til Grundtvig-Studier 1948-2008, II
}

\section{Af Aage Jørgensen}

Guiden er bredt favnende, men ikke alt omfattende. Organiseringen er diskutabel af den enkle grund, at Grundtvigs liv og forfatterskab, og følgelig også hvad der er skrevet derom, konstant truer med at sprænge kategoriseringerne. - Del I stod i GrSt 2009. Del II hér fokuserer på den pædagogiske side af sagen (incl. højskoletanken), samt på virkningshistorien - i Danmark, Norden, Europa, verden.

\section{Grundtvigs padagogiske tanker}

Som overmåde bekendt er "Skolen for Livet" Grundtvigs pædagogiske løsen. Hovedværket på dette felt er K. E. Bugges disputats (1965), med opfølgning i form af tobindsudgaven af Grundtvigs skoleverden $i$ tekster og udkast (1968). A. Pontoppidan Thyssens opposition i GrSt 1965 accepterer ikke uden videre hovedsynspunktet, men finder arbejdet overordentlig fortjenstfuldt, i høj grad værd at diskutere, fordi det baserer sig på et omfattende, til dels utrykt materiale, fordi det fastholder Grundtvig på "hans inspirationskilder og baggrund i samtidens pædagogiske tænkning og i den danske pædagogiske debat", og fordi synspunktet viser sig "samlende og befrugtende for det dygtige detailstudium af Grundtvigs pædagogiske tankeudvikling og dens baggrund i samtiden".

Bugge anfører, at impulser fra tidlig romantik hos Grundtvig fremmer en "idealbestemt" pædagogik til personlighedens dannelse, men at denne position o. 1808 forlades til fordel for en trinvis udvikling af en ny livsorientering frem til o. 1830, hvor en periode karakteriseret ved højskoleskrifternes afklaring sætter ind. Pontoppidan Thyssen finder alt dette lære- og perspektivrigt, men ikke, at det er grundlag nok til forståelse af Grundtvigs tanker. Han pointerer, at Grundtvig ret konsekvent formulerer disse i polemiske kontekster, som led i "et kulturelt opgør", som endda ses i spæd udfoldelse allerede på Langeland: lysten skal drive værket. Men Grundtvig er inkonsekvent, han giver udtryk for romantisk-idealistiske tankegange samtidig med, at han gør udfald mod idealismens sværmeri. Polemikken rammer både romantikken og ikke mindst oplysningstiden med dens latinske dannelse. Nordens Mythologi er et overmåde polemisk værk, kulminationen af den hudfletning af det "romerske" uvæsen, som Grundtvig indledte 0.1825 , fordi det essentielt ville "beherske". Når han fordrer levende undervisning, betyder det, at "fortidens liv virkelig genopstår i 
det øjeblik, hvori man taler om den". Det levende ord ikke blot melder om liv, men skaber det. Polemikken ramte også den realskole, som stænderforsamlingerne debatterede. Den ramte i det hele taget bredt, "målet var simpelthen en sandere oplysning og livsforståelse, end han fandt i tidens åndsliv". Fremme ved højskoleskrifterne anker Pontoppidan Thyssen over, at disputatsen ikke graver dybt nok i disse. Den handler for så vidt mere om skoletankernes tilblivelse end om deres udfoldelse. Han så den derfor gerne videreført på det anlagte grundighedsniveau ind $i$ alderdomsforfatterskabet.

Bugge har siden skrevet en række afhandlinger med uddybning og indtrængen i dele af komplekset, for eksempel i GrSt 1998 en opposition ved Bosse Bergstedts disputats Den livsupplysande texten (1998), der tilfører Grundtvig-forskningen en ny tilgang ved at fokusere på de pædagogiske teksters sproglige og litterære side, blandt andet med inddragelse af nyere retorikteorier. Det centrale anliggende er forholdet mellem skriftlighed og mundtlighed, men efter Bugge er det tekstlige grundlag for Bergstedts diskussion heraf unødigt snævert. Trods alt roser han arbejdet for at have anlagt et nyt syn på de relevante tekster og analyseret dem med respekt for deres gådefuldhed.

I "Nogle grundbegreber i Grundtvigs pædagogiske tanker" (GrSt 2008) skelner Bugge definitorisk mellem højfrekvente og fundamentale begreber og udsøger sig blandt de sidstnævnte to, der tilmed kan siges at være primære: liv og lys - mens oplysning er sekundær, eftersom det beror på primærbegrebet (som ganske vist kan være teologisk såvel som pædagogisk funderet). Livet og lyset er i øvrigt "Tvillinger bolde", uadskillelige undtagen ved døden (jf. "Skolen for Livet" versus "Den sorte Skole"). De fire siders brødtekst er til overvejelse, samtiden anbefalet!

Også Regner Birkelund har i disputatsform bidraget til belysning af den pædagogiske tankeverden, især af dens genese. Som et forskræp til disputatsen fungerer artiklen "Kend dig selv. Om det sociale individ og det sunde samfund" (GrSt 2005), der med udgangspunkt i en Marielyst-tale undersøger den græske inspiration, som føres helt tilbage til konrektor Stougaards "oplivende og oplysende" undervisning i det mørke, som ellers prægede Aarhus Katedralskole. Pædagogikken dér som overalt i datidens samfund var nytteorienteret, og indterpning var dens foretrukne metode. Grundtvig ville på græsk vis, at eleverne skulle lære sig selv at kende. Målet var selvudvikling for det menneskelige fællesskabs skyld. Den græske inspiration er efter Birkelunds mening blevet "underbetonet". Dens hovedkilder er Platon og Aristoteles. Platons "tanker om samtalens og det vingede ords nødvendighed i oplysningsøjemed" greb ham, og ligeså statsforfatningstankerne. "Samfundsdannelse begynder med den enkeltes oplysning og 
dannelse." Platon formulerer sig her i klar modsætning til sofismen, der retorisk ville pådutte folk en mening - altså besnakke dem. Sand erkendelse drejer sig ikke om snak, men om forløsning af noget i sjælen, der allerede er latent til stede, og virker ud i "det etiske handlingsliv". Det skrevne ord tenderer rent ud sagt imod fordummelse af "det virkelige Menneske-Liv". Samtalens levende ord sammenføjer sig med Aristoteles' tanke om, at man egentlig først erkender sandt ved at hengive sig i handlingslivet. Præcist som Grundtvig talte om at "blive klog paa Menneske-Livet" ved at leve det. Og her kommer så den aristoteliske venskabsfilosofi ind i billedet. Jo mere venskabet strukturerer, jo mindre behov er der for lovregulering. Med venner i lys at tale, det er måden, også samfundsmæssigt. I 1850 ligestillede Grundtvig simpelthen fædreland, modersmål og vennelag.

Ægte erkendelse har med livsduelighed at gøre. Og livsduelighed vil sige at opgå i det venlige fællesskab, i vennelaget. Livsoplysning kan ingensinde afstedkommes ved tvang. Den sorte skoles eksamenstyranni gør den til "Skolen for Døden". Glæden indgår i Grundtvigs samfundsutopi om den oplysende vennesamtale. Livsoplysning er således frugt af en eksistentiel erkendelse, der fører til livsduelighed. Livet går foran lyset. Således skulle den folkelige livsoplysning muliggøre det "ægte folkestyre".

Selve disputatsen, Frihed til folles bedste. En oppositionel stemme fra fortiden (2008), og specielt hoveddelen "Den græske Grundtvig frihed, lighed og venskab", fik en hård medfart i Carl Henrik Kochs anmeldelse (GrSt 2009), der anfægter selve den måde, hvorpå inspiration og påvirkning overhovedet forstås. Birkelund ser nok Grundtvig i historisk kontekst, men yder ikke andre samme service. Han godtager ukritisk Grundtvigs synspunkter, overser f.eks. H. N. Clausens hegelkritiske opfattelse og bortser fra følelsens rolle som handlingsimpuls i Kants moralfilosofi. "Frihedens glimrende Tider" lå efter Grundtvigs eget udsagn før Platon og Aristoteles, skønt de hævdes at have inspireret ham. Koch finder intet indgående Platon-kendskab hos Grundtvig. Grækerens samfundsmæssige lagdeling og dannelsesmæssige differentiering minder ham ikke meget om den "Vidskab", Grundtvig propagerede. Birkelunds Platon er "lidt af en frihåndstegning". At Aristoteles' venskabsbegreb for Grundtvig skulle være "det altafgørende omdrejningspunkt", anfægtes også. Lykken er for Aristoteles et gode, hvori venskab indgår som delbegreb - men er det nyttebaseret venskab, Grundtvig efterspørger? ${ }^{1}$

1 Jf. Jens Holger Schjørring, "Om Regner Birkelunds Grundtvig-disputats", Dansk teologisk Tidsskrift, 72, 2009, 57-72, der som afhandlingens "iøjnefaldende" fortjeneste fremhæver, at den på tværs af alle forskningens inddelin- 
Hvor Bugge finder Grundtvigs frihedsbegreb "nordisk", finder Birkelund det altså "græsk". Koch finder det uafklaret hos Grundtvig selv - og også hos Birkelund, hvis disputats ikke præsterer "en egentlig videnskabelig analyse" af begrebet.

"Det Chinesiske Examens-Væsen" er titlen på et bidrag af K. E. Bugge i GrSt 2007. Udtrykket er Grundtvigs og sigter mod "den sorte Skole", men stammer i realiteten fra et portugisisk, til italiensk oversat, værk om orientalske opdagelsesrejser, som han benyttede i forbindelse med udarbejdelsen af Haandbog $i$ Verdens-Historie - og pointen dér er, at de kinesiske embedsmænd var overordentlig sendrægtige i eksaminationen af en tilrejsende delegations papirer, da den i 1517 kom til Canton.

\section{Grundtvigs oplysningstanker}

Hvad blev der af Grundtvigs drøm om "Skolen i Soer", spørger Gustav Albeck i GrSt 1983. Det oplagte svar, at den blev realiseret i folkehøjskolebevægelsen, er "næppe fyldestgørende". De ældre engelske universiteters kollegiesystem såvel som planer for et moderne (folkeligt, latinfrit) universitet i London nærede ideen, der skulle skabe en levende vekselvirkning mellem akademisk og folkelig dannelse, en art humanistisk pendant til det af H. C. Ørsted oprettede selskab til naturlærens udbredelse. Den tanke lagde Rigsdagen i 1849 på is. Men i forskellige reformuleringer kom den til diskussion ved flere senere lejligheder: med Rasmus Nielsen som fremmeste talsmand i den såkaldte Sorø-kommission 1866-67; på en række ledende højskolefolks Tivolimøde i 1878, hvor forestillingen om en statslig højskole viste sig uspiselig; i Rigsdagen i 1878, hvor Estrups kulturminister gav bolden op til forhandlinger om "et folkeligt Universitet" (Chr. Berg lancerede i debatten betegnelsen "Folkeuniversitetet"), i 1880, hvor et lovforslag om oprettelse af en statshøjskole i København ikke nåede til realitetsbehandling på grund af valgudskrivelse, og i 1888, hvor V. Pringel slog til lyd for "en videnskabelig højskole i Århus, et moderne universitet, der kunne blive en modvægt mod det gamle, forbenede universitet på Frue Plads, for så vidt som det skulle være forpligtet til at arbejde i folkeoplysningens tjeneste"; på et møde i 1907, hvis deltagere bad regeringen gendrøfte spørgsmålet om en jysk højskole, men hvor der dog vist var større sympati for et jysk universitet (der jo realiseredes $\mathrm{i}$ 1928). Undervejs delte højskolefolkene sig - nogle ville kun lege med på Grundtvigs oprindelige præmis, mens andre gerne så det folkelige akademi etableret i samspil med akademiske uddannelser.

ger af forfatterskabet understreger betydningen af "en tværfaglig analyse af den hele Grundtvig". 
Ove Korsgaard plæderer i "Grundtvigs oplysningstanker - om at knytte bånd og løse knuder" (GrSt 2000) for, at den pædagogiske og den skolehistoriske tilgang suppleres med et mindre påagtet tredje forskningsfelt: oplysningstankerne. Men før han når til oplysningen, foretager han en afklaring. Det bør kunne diskuteres, om højskolen er en realisering af "Grundtvigs samlede oplysningsprogram" - som vel at mærke udfoldes allerede i Danne-Virke-årene, især i artiklen "Kirke, Stat og Skole". Grundlæggende gælder det "forbindelsen mellem det individuelle, folkelige og universelle". Højskolen må sigte mod folkelivet, universitetet mod universel erkendelse. I Statsmoessig Oplysning skitseres skolesynet samlet, endda bragt på triadiske formler. Skolen bliver stedet for mediering af frihedstrang og samfundstvang. Den skal forebygge, at tingene går i hårdknude - hvilket kan forekomme, når individet for det fælles bedstes skyld må lægge bånd på sig og agere ansvarligt. Den statsmæssige (senere: folkelige) oplysning er remediet hertil. Men "oplysning" er jo ikke en entydig størrelse. Grundtvig nåede frem til, at sand oplysning er, hvad der - nå, ja, oplyser den universelle treklang individ, folk, menneskeslægt. Et folk er en refleksionskategori omfattende grundelementerne sproget og historien. Ole Vind anfører, at Grundtvig baserer sit begreb på "forældede synspunkter", men Korsgaard gør gældende, at det folkeliges konstruktive betydning i samfundsudviklingen ikke står og falder med, at en bestemt fortolkning af det er blevet passé. Spørgsmålet om den folkelige dannelses samspil med den universitære udgør et andet problem. Herom taler skriftet Lykønskning til Danmark med Det Danske Dummerhoved og Den Danske Høiskole. Folket vil ikke fortabe sig så meget i "sit Eget", at det mister organet for "det saakaldt Fremmede", det vil ikke lukke af for udsynet mod "den universelle horisont". Göteborg-universitetet skulle beflitte sig på tydeliggørelse af den dybe sammenhæng mellem partikulariteten og universaliteten. Oplysningsprogrammet blev realiseret "i stærkt begrænset og beskåret skikkelse" via folkehøjskolerne, som blev båret frem af de nationale strømninger, specielt efter 1864nederlaget. Dets "universitetsdimension" derimod forblev urealiseret. I vor tid er der et ikke mindre behov for refleksion over samspillet mellem individet og globaliteten - altså for "at interessere sig for helhedssynet i Grundtvigs oplysningsprogram".

\section{Den grundtvigske folkehøjskole}

Rødding Højskole var som bekendt den allerførste. Om det var en virkeliggørelse efter Grundtvigs vision, forsøger Thorkild C. Lyby at finde ud af i en artikel i GrSt 1999, med afsæt i skolens stedmoderlige behandling i Helge Grells skrift Vision og virkeliggørelse fra 1998. 
Lyby finder intet forbehold i talen på Skamlingsbanken. Den ny skole placeres præcist der, hvor det danske folk "har mod til at ligne sig selv" - og han ser frem til virkeliggørelsen. Men vitterligt kom det til debat om skolens grundtvigske karakter. Adjektivet angiver for Lyby, at man ved skoleetableringen har været Grundtvig-inspireret, uanset om man nu har fattet hans tanker til fulde eller efter bedste evne. Buddingen vil dømmes på smagen, ikke på opskriften. Hvad angår Rødding, spillede en national interesse tydeligvis ind. Stænderforsamlingen aktualiserede behovet for gode danske mænd med en slags dannelse, og i øvrigt trak det jo op til national kamp. Chr. Flor delte fuldt og helt Grundtvigs anskuelser, som det fremgår blandt andet af den af ham udarbejdede oprindelige skoleplan. Det samme må siges om Fr. Helveg og Sofus Høgsbro, men med krigen overstået og danskheden sikret kom der under sidstnævnte brudlinjer til syne, der kan være forvirrende nok, også fordi personlig kemi spillede ind, men hvor der dog overordnet tegnede sig tre positioner: en grundtvigsk-folkelig, der sigtede mod åndelig vækkelse; en grundtvigiansk-religiøs, der sigtede mod kristelig vækkelse; en praktisk, der sigtede mod landbrugsfaglig dygtiggørelse. At Grundtvig så forholdt sig tvetydigt til skolen, er en anden sag. Han kom der ikke og var ikke just Høgsbro til nytte i de vanskelige situationer. Lybys forklaring er psykologisk - den kuldsejlede statsfolkehøjskole i Sorø sad ham i kødet og forhindrede ham i at erkende, hvad Ingemann indså allerede i 1849: "Jeg mener (...) med Flor, at flere smaa Røddinger ere de bedste højere Folkeskoler." Derfor ikke-nævnelsen af Rødding ved indvielsen af Marielyst. Grundtvigs problem, altså!

"Højskole i 150 år" hedder et bidrag af Hans Henningsen i GrSt 1995, som ud fra fire jubilæumspublikationer påpeger nogle vigtige problemstillinger. Rødding illustrerer udviklingen fra det samfundsorienterede mod det landbrugsfaglige, i Hans Lunds forstandertid med integration af "bondens livsform" i højskolesynet. Ask, den sidste af de såkaldte Bjørnbak-skoler, skulle fra begyndelsen tilgodese den lokale landboungdoms oplysningsbehov, men orienterede sig efterhånden bredere, mod grundtvigsk folkelighed. Flagskibet Askov magtede ifølge Gunhild Nissens bidrag til bogbunken ikke at vriste sig fri af bondekulturen i forbindelse med udfordringen o. 1890 fra fritænkeriet og udviklingslæren. Den "radikale frihedslinje" blev først for alvor taget op af Hal Koch på Krogerup, mens Askov jo udgrænsede sin radikale fløj i 1968-71. Henningsen skildrer højskolens daværende krise som en fiksering på frihedskamp i og for sig, med forglemmelse af den ligeledes fornødne tale om indhold og mening. Krogerup blev Hal Koch en skuffelse, fordi samtalen drejede fra fællesskab og demokrati mod eksistensproblemer og litteratur. Ikke desto mindre konkluderer 
Henningsen, at Kochs virke på eminent vis har bidraget til "at omplante Grundtvigs tanke om samtalen og det folkelige fællesskab fra enevældens forudsætninger til det demokratiske samfund".

Ove Korsgaards artikel "Hvordan erindres folkehøjskolens historie?" (GrSt 2007, efter fejlbehæftet forsøg i GrSt 2006) tager afsæt i det forhold, at erindrede begivenheder ændrer sig over tid, blandt andet afhængig af magtforhold. Den herskende mening er nok, at dannelse er højskolefint, mens faglig indlæring udgør en forurening. Hos Grundtvig løb grænsen mellem det dansk-folkelige og det latinskklassiske. Han kunne enes med Madvig om, at målet var at vække "det høiere i Mennesket", men jo ikke om, at de eksisterende skoler var ikke-danske. En særlig, "Charakteren af Danskhed monopoliserende Underviisningsanstalt" - akademiet i Sorø, altså - kunne Madvig ikke bruge til noget. Den almene dannelse skulle gennemsyre hele universitetsforberedelsen. Dette udelukkede jo i øvrigt ikke højere bondeskoler - og disse måtte for Grundtvig gerne omgive sig med avlsbygninger og værksteder. Det gængse var da også kombinationen. Det gav gnidninger i Rødding, da Høgsbro advokerede renhedslinjen. Siden kom der megen forurening til, f.eks. elektrikeruddannelsen ved Askovs forsøgsmølle. Men forholdet mellem dannelsesformidlingen og den erhvervsfaglige eller studieforberedende undervisning er aldrig blevet kortlagt. Håndværkerkvalificeringen blev definitivt udskilt 0 . 1940, landbrugskvalificeringen først o. 1970. Siden har erindringen hæftet sig forbavsende lidt ved, at der skulle brød på bordet, om man da ikke ville sulte for ideens skyld - for nu at alludere til en kendt formulering af Ludvig Schrøder. Konklusionen kan da blive: "Højskolens fremtid afhænger af en anden forståelse af dens fortid end den i nutiden dominerende."

På Vallekilde fulgte man til fulde opskriften. Ernst Trier ville "fremme vekselvirkningen mellem åndsliv og produktionsliv, mellem myter og mønter, mellem dannelse og uddannelse". Det fremhæver Korsgaard, og det uddybes i den følgende artikel af Pål Bødtker Walsted om Triers Grundtvig-reception. ${ }^{2}$ Trier var Grundtvigs fortrolige og fik gode råd af ham. Han må have gouteret formuleringen fra skriftet Til Nordmoend om en Norsk Høi-Skole om, at oplysning og dannelse var "et tomt Hjerne-Spind", om undervisningen ikke forbandt sig med arbejdsduelighed. Vallekilde integrerede med sjælden konsekvens dannelsesfagene (modersmål, mytologi, historie), de praktiskæstetiske fag (blandt andet kunsthåndværk) og den erhvervsrettede undervisning og var tillige en kristelig vækkelsesskole baseret på forestillingen om det gudbilledlige menneske. Trier var som Grundtvig

2 Walsteds dr.polit.-afhandling Dannelse og yrkesutdanning $i$ den grundtvigske tradisjon blev forsvaret i Trondheim i 2006. 
fortrolig med et handlingsrettet fromhedsideal med rødder $\mathrm{i}$ jødiskkristen tradition. Han vidste til fulde, at hvad hånden former, er åndens spor, og at der intet modsætningsforhold bør være.

\section{De folkelige bevægelser}

"Nationalitet og kirke i Danmark og Slesvig-Holsten 1770-1920 med særligt henblik på Grundtvigs betydning" er den ambitiøse titel på en desværre uafsluttet artikel af A. Pontoppidan Thyssen i GrSt 1999. Den supplerer og korrigerer et arbejde fra 1952 af Troels Fink, der pointerede, at "ingen enkeltmand i dansk åndsliv har haft større betydning for det danske Sønderjylland end Grundtvig". Artiklen redegør grundigt for spændingerne i kongens lande mellem dansk og tysk i perioderne 1770-1800 og 1800-1849 - så langt rækker den - med fokus ikke blot på samfundsmæssige forhold, men også på kirkepolitiske. Den tyske indvandring var betydelig og vigtig for statsadministrationen, men skabte uro i oplysningsårtierne. Struensees arrogance miskrediterede tyskerne, Guldbergs indfødsretslov vakte dansk begejstring, men efter kronprinsens revolution besatte tyskerne atter topembedsposterne. Ove Mallings skrift om danske, norske og holsteneres store og gode handlinger definerede $\mathrm{i}$ det væsentlige periodens patriotisme. Voksende spændinger karakteriserede som bekendt første halvdel af 1800-tallet. Lovgivningen tilsigtede større ensartethed i helstaten (og højere skatter), hvilket generede godsejerne. Forventningerne til et tysk forbund også omfattende hertugdømmerne under samme forfatning tiltog. Uwe Jens Lornsens forfatningsudkast stræbte liberalistisk mod at gøre tredjestand "bærende" - og blev jo svagt imødekommet af kongen, blandt andet med stænderforsamlingerne. De nationale modsætninger blev trukket op o. 1840, især på grund af Christian VIII's sprogreskript, som fremkaldte Hiort Lorenzens bekendte demonstration og kravet om en fællesforfatning for Danmark og Slesvig, med tilhørende modtræk fra "tysk" side. En bevægelse med den antirationalistiske prædikant C. Harms i spidsen strammede op og nærmede den slesvig-holstenske kirke til den tysk-lutherske, blandt andet med krav om en ny kirkeforfatning. Denne "kirkeligt-sindede" bevægelse udgjorde den tidlige slesvig-holstenske nationalismes kirkelige fløj. Den sigtede målrettet imod udelukkelse af danskuddannede lærere og præster. På dansk side gik Grundtvig en anden vej med den traditionsforankrede anskuelse, som han lancerede i Kirkens Gienmale, og som jo påførte ham fordømmelse og censur - og nærmede ham til den såkaldte forsamlingsbevægelse. Han fordrede religionsfrihed inden for en neutral statskirkelig ramme og skabte med højskoletankerne det folkelige fundament for sit arbejde; det kristelige måtte så komme på 
andenpladsen. "Livets Sødhed, Modersmaalets Liflighed, Fædernelandets Deilighed" udbredte sig for mennesket, som så frit kunne "takke ham som opvakte dig". Gennem en lang række foredrag udbredte Grundtvig budskabet, først i København, så også hos de dansktalende nordslesvigere, dér dog pr. stedfortræder: Chr. Flor fra det ellers for den slesvig-holstenske sag ret så aktive universitet i Kiel. Bladet Dannevirke blev stiftet, der blev afholdt møde på Skamling, en slesvigsk forening blev dannet, Rødding fik sin højskole, osv. Og alt sammen understøttet af gårdmænd, som havde fået blod på tanden $\mathrm{i}$ stænderforsamlingerne. Sendrægtigere gik det i den nordvestlige del af området, indtil en række yngre grundtvigske præster rykkede ind og markerede sig. - Herefter skildres $i$ to afsnit Treårskrigen med fokus på den slesvig-holstenske kirkekamp og på den nordslesvigske folkerejsning. Hvad angår sidstnævnte, vurderede de tysksindede embedsmænd, at det var bøndernes mangel på politisk dannelse, der havde gjort dem til ofre for dansk propaganda, især fra præster og lærere. Man havde gerne set Grundtvig inddraget i diskussionen af netop denne sag. ${ }^{3}$

Kim Arne Pedersen pointerer i sin nekrolog over Vagn Wåhlin (GrSt 2009), at han stak af fra mainstream-forskningen ved at insistere på, at Grundtvig og grundtvigianismen burde ses "som led i én samlet bevægelse". Man må tage udgangspunkt i en forestilling om sammenhæng mellem socio-økonomiske og kulturelle forhold, dog således, at elementer i den grundtvig-koldske skoletænkning trods ændrede forudsætninger vedblivende trækker spor op i nutiden. Således lagde han grunden til en tænkning omkring national identitet, hvor det mentalitetshistoriske kom til at stå mere og mere centralt.

Wåhlins betydeligste bidrag til en "kvalitativ forståelse" af de folkelige og sociale bevægelser fremkom i GrSt 2003. ${ }^{4}$ Talen er, som oplyst $\mathrm{i}$ undertitlen, om "en indkredsning af et vanskeligt historisk problemkompleks". Wåhlins erkendelsesinteresse vedrører spørgsmålet om, hvordan en virkningshistorie afstedkommes, og netop gennem "de folkelige bevægelser". Artiklen giver en hæsblæsende, komprimeret, historisk dimensioneret fremstilling af mulighedsbetingelserne for det grundtvigske input - på baggrund også af enevældens indretning (regulering, overvågning) af adfærden i det offentlige rum, også med blik på de forskydninger fra statspatriotisme til nationalbevægelser, som jo finder sted. Det nationale forstås "som en kollektiv og følelsesladet be-

A. Pontoppidan Thyssens disputats Den nygrundtvigske Bevagelse (1958) blev anmeldt af Gustav Albeck i GrSt 1958.

4 Engelsk oversættelse i GrSt 2006. Indføjet er i titlen "religious", trods den indledningsvise beklagelse af, at "den kirkeligt-kristelige dimension" er ladt ude af betragtning (ligesom kvinde- og afholdsbevægelsen). 
vidsthed om fædreland og fællesskab". Det fordrer et folk i et geografisk rum med en sammenknyttende historie og et fælles sprog, med et fælles værdigrundlag for kulturelle og religiøse udtryksformer, hvor alt dette er inderliggjort til "at leve med, føle for og aktivt virke $i$ dette kvalitative værdifællesskab". Man taler i Danmark om "folkelige bevægelser", hvor angelsaksisk inspirerede discipliner ofte taler om "sociale bevægelser". Wåhlin peger også på forskellen mellem bevægelserne og deres organisationer og institutioner - løsenet var levende vekselvirkning, ikke topstyring. Bevægelser er gerne langtids-, men ikke altidsholdbare. Forsamlingshuse og bladprojekter nedlægges. Afideologiseringen har taget den livgivende solidaritet ud af arbejderbevægelsen. Frivillighedsprincippet står stadig stærkt på lokalt plan, men trues af den kropskulturelle professionalisering (kapitaliseringen af elitesporten, osv.). Men generelt konflikter frivilligheden jo med en samfundsmæssig tvang (statslig modernisering, markedsøkonomisk tryk). Når ånden siver ud, mister bevægelserne deres "samfundsstrukturerende og samfundsforandrende evne og betydning", og så må de enten dreje nøglen om eller se sig opslugt af "det offentlige".

Artiklen løber ud i forskningsovervejelser. Hvis Grundtvigs virkningshistorie og de folkelige bevægelser skal have større opmærksomhed, må tværvidenskabelige tilgange tage over, og opmærksomheden rettes mod vekselvirkninger og interaktion. Teologer og litterater må give plads til folk med disse interesser og kompetencer. Perspektivudvidelse og "øget opmærksomhed på dagsaktuelle og globale problemstillinger" skal til.

Hvor Wåhlin skitserer en udvidet forståelsesramme for Grundtvigforskningen, er Niels Kayser Nielsens ærinde i artiklen "Nationalisme, disciplin og folkelighed i 1800-tallets Danmark" (GrSt 2003) et snævrere: at anlægge en kropskulturel synsmåde som baggrund for en begribelse af det grundtvigske engagement i legemsøvelser. Artiklen lokaliserer to gymnastiktraditioner i 1800-tallet. Med udspring i rationalismen en filantropisk indsats til moralsk forædling af det naturgivne "materiale" - og desuden en militært inficeret, præstationsorienteret disciplineringstankegang. Sidstnævnte kom til at dominere, men lod sig senere indoptage i den bredere, af Ling-gymnastikken prægede grundtvigske forestillingskreds. Grundtvigianismen fik efter 1861 en sammenknyttende funktion i skyttebevægelsen. Samfundsudviklingen beroede på det kropslige område på en "kombination af disciplin, dannelse og kropslig frigørelse", baseret på erfaringer "af både tvang og kontrolleret lyst”.

Også Henning Eichberg har beskæftiget sig med, hvad resumeoverskriften noget anstrengt kalder "kropshøjskolens vej" (GrSt 2006) - fra idrættens forankring i 1800-tallets folkelige bevægelser til 1900- 
tallets tiltagende specialisering, udtrykt spektakulært i eliteidrætten. Samtidig er højskolens principielt dialogiske undervisning $i$ almindelighed kommet under et stigende formaliseringspres, der gør det vanskeligere at fastholde idealet om, at alle konkurrencedeltagere er vindere.

\section{Grundtvig i nutidig reception}

"Grundtvig på anklagebænken" har Kim Arne Pedersen kaldt et bidrag, der over 68 sider gør rede for "hovedlinjer i de sidste ti års danske Grundtvig-reception og deres forhold til centrale motiver i Grundtvigs forfatterskab og dets virkningshistorie" (GrSt 2002). Pedersen konstaterer indledningsvis, at "holdningen i den danske offentlighed til Grundtvig og den grundtvigske arv i de seneste år har været overvejende negativ", blandt andet som følge af samfunds- og kulturdebattens polarisering. Enten tages Grundtvig til indtægt for danskhed \& kristendom, eller også affærdiges han for legitimering af netop denne kobling. Pedersen skitserer indledningsvis receptionen fra Edvard Brandes' kølige jubilæumsartikel, der i 1883 sendte Morgenbladet til tælling - via Frederik Borgbjergs socialdemokratiske indskiben sig i dansk identitetstænkning, Hal Kochs humanistiske Grundtvig-brug under besættelsen og Kaj Thanings livsfilosofiske læsning af Grundtvig helt frem til udnyttelsen af hans danskhed i EF-modstandskampen. Fra 1990'erne sker der en kobling i identitetsdebatten mellem danskhed, nationalisme, fremmedfjendskhed, selvgodhed, osv. Grundtvigs antidemokratisme før grundloven, synspunktet (udfoldet i debatten med Goldschmidt i 1849) om jøderne som "fremmede", forestillingen om danskerne som udvalgt folk og modstanden mod fattigforsørgelse trækkes af stald og skamrides, frem for at blive forstået kontekstuelt og i dybden. Kim Arne Pedersen finder denne udvikling stimuleret blandt andet af Ole Vinds disputats Grundtvigs historiefilosofi, 1998, med dens hævdelse af, at Fichte-påvirkningen kommer til at danne basis for "Grundtvigs bibelsk-fundamentalistisk funderede skabelsesmyte". For Dansk Folkeparti bliver Grundtvig derimod årtusindets dansker - mens grundtvigianismen opfattes som et Grundtvig-svigt, således af Jesper Langballe (i Tidehverv, 2002), og vel at mærke med henføring af skaden til Thanings hævdelse af den klare adskillelse af menneskeligt og kristent efter 1832. Langballe må dog på et punkt lægge luft til Grundtvig, der "fremhævede frihedens og frivillighedens betydning for ægte fædrelandskærlighed", hvor Langballe mener, at "ikke kærlighed, men lov og tvang er bærende i virkelighedens verden". Pedersen fremhæver også Henning Tjørnehøjs insisteren på, at Grundtvig politisk og socialt var reaktionær, i hvert fald foretrak kombinationen af 
enevældig monark og folkeforsamling frem for repræsentativt demokrati. Også Grundtvigs oplysningstanker er blevet sat under anklage, især af Søren Ehlers, der mener, at det særlige ved dansk folkeoplysning, incl. højskolerne, er de offentlige tilskud. Endog indefra formuleres der alvorlig kritik af højskolens traditionsforvaltning. - Kim Arne Pedersens pointe er nu, at der før den endelige afskrivning af Grundtvig kan være grund til "en fornyet beskæftigelse med forfatterskabets kristent-teologiske udgangspunkt og nerve". Han påtager sig faktisk at skitsere en sådan ny neddykning. Han præsenterer udsagn, der "kan kaste lys ind over, hvilke elementer i forfatterskabet der undslipper både Grundtvigkritikerne og de højreorienterede Grundtvigfortolkere", således at for eksempel bestemmelsen af Goldschmidt som "en fremmed" făr komplicerende dybde og afvisningen af ydmygende og menneskerettighedsindskrænkende fattighjælp afbalanceres af tanken om frivillig næstekærlighedsbaseret hjælp. Om konfusionen består, er det rigtignok på et højere niveau.

\section{Højskolen i den aktuelle debat}

Martin Groh pointerer i "Zwischen Tradition und Moderne" i GrSt 2000, at de seneste årtier har "forandret vilkårene for folkeligheden", men uden at højskolen har involveret sig overbevisende offensivt i debatten. Han efterlyser en art fællestilkendegivelse med kritisk statusopgørelse og "klare, fælles målsætninger for fremtiden".

"Grundtvig og folkehøjskolen i dag" er fællestitlen over tre artikler af Henrik Wigh-Poulsen, Jes Fabricius Møller og Kim Arne Pedersen i GrSt 2004. Wigh-Poulsen ser et påtrængende behov for, at "den bløde midte" besinder sig på et skabelsesteologisk reformuleret grundlag med afvisning af både "midthalvfemsernes grundtvigkritik" og traditionens redningskorps. Det gælder om at komme "ned i maskinrummet" for at reflektere forfra og sætte nye, levende, fremad- og udadvendte ord på den lidt stivbenede sag. - Fabricius Møller konstaterer med basis i folkehøjskolernes fælleskatalog, at Grundtvig er på vej ud. Man vil give eleverne succes, kompetence, færdigheder, osv., en i realiteten gammel nyhed. Og sløret mellem "den Gamle" og os bliver tykkere og tykkere. Han er, blandt andet takket være den grundtvig(ian)ske forvaltning af arven, gået hen og blevet til en myte. Ja, har egentlig sejret sig ihjel. I begyndelsen blev det diskuteret, om spat hos heste var et legitimt undervisningsemne, i 2004 blev der som den naturligste sag af verden holdt overvægtskurser. - Også Kim Arne Pedersen skitserer en tredje vej, men på grundlag af diskussioner i forummet Nyt syn på Grundtvig. Med reference til H.-G. Gadamers traditionsbegreb (altså med afvisning af Michel Foucaults begreb om vidensar- 
kæologi) vil Pedersen drage Grundtvig ud af "mytens ruiner". Ved at læse og tolke ham "ud fra virkningshistorien", så forandringen medtænkes, vil han fremhæve hans positive forbindelse med moderniteten og afstedkomme "en fordybet indsigt $\mathrm{i}$ betydningsvidden i de grundtvigske begreber". Målet er "at holde højskole på tidens vilkår, men ikke på dens betingelser".

I GrSt 2006 diskuterer Kim Arne Pedersen "Dannelsesbegrebet som element i folkehøjskolens selvforståelse". Vis-a-vis Ove Korsgaards pointering af, at der er sket et brud, fastholder han sin Gadamer-understøttede kontinuitetsforståelse, blandt andet med inddragelse af den aktuelle Grundtvig-reception hos praktiserende højskolefolk, især Jørgen Carlsen. Hos ham står dannelsesbegrebet centralt, understøttet af åndsbegrebet og frihedsbegrebet, sidstnævnte som implicit tilstedeværende. En sådan nutidig tolkning beror på en vægtningsforskydning. I Carlsens åndsbegreb høres ekkoer af Grønbech, Løgstrup og Thaning, men det er dog sikkert forankret i den berømte formulering fra Nordens Mythologi, at mennesket ikke er en abekat, men et guddommeligt eksperiment, hvor ånd og støv gennemtrænger hinanden. Den åndelige dimension udgør "det intersubjektive $\mathrm{i}$ menneskelivet". Men hvor Grundtvig knytter teleologien til en omfattende forståelse og forklarelse af menneskelivet, knytter Carlsen det snævrere til individet. Det gådefulde hos ham er "lig med selve dét, menneskets blik skal åbnes for, dét, der udgør kernen i dannelsen". Hvad angår frihedsbegrebet, så drøftes det i relation til Korsgaard, fordi han bortser fra det. Pedersen knytter an til Holger Kjærs udlægning, idet den kommer "tæt på udgangspunktet". Højskolefriheden er en frihed fra statsindblanding, men først og fremmest en frihed fra eksaminer, til sikring af menneskeudfoldelsen mod bundlinjefiksering. Skønt Korsgaard har ret i, at folkehøjskolen har ændret selvforståelse, er der stadig brug for den i en tid, hvor politikerne fokuserer entydigere på erhvervslivets tarv end på "de grundtvigske skoletankers dannelsesorientering", og hvor det virker, "som om statslig kontrol skal afløse tanken om frihed til folkelige institutioner".

Også Thorkild Lyby har diskuteret det grundtvigske dannelsesbegrebs rolle "mellem national dannelse og erhvervsorienteret uddannelse" (GrSt 2004). Samfundsudviklingen har medført, at arven forvaltes i mangfoldige aftapninger, dog med "fælleslivet på højskolen" som afgørende ramme om personlig afklaring - og just i vor moderne, fragmenterede og internationaliserede samfund forekommer det særlig vigtigt, at "den folkelige dannelse holdes i live". 


\section{Grundtvig og verden}

Grundtvigs potentiale som eksportartikel er behandlet oversigtligt af Flemming Lundgreen-Nielsen (GrSt 1997), med udgangspunkt netop i de forhold, der gør det vanskeligt for Grundtvig at blive et essentielt dansk bidrag til "World Culture". Der er selve lyriciteten, og der var for prosaens vedkommende metoden med at fremskrive den forønskede klarhed, som dog alligevel ikke kan opnås før i tidens fylde. Videre behandler artiklen en række "recent initiatives", som har skullet tjene til brobygning hen over vanskelighederne - konferencer blandt andet $\mathrm{i}$ Köln, Århus og Chicago, med "tilhørende" publikationer. Grundtvig har et stort potentiale. I den snævre kreds af angelsaksiske forskere indtager han en fremtrædende stilling. Der går en linje fra hans folkelighedsforankrede teologi til den moderne økumeniske teologi. Hvad angår højskolen, så er det afgørende jo den folkelige forankring, ikke den akademiske fundering, og derfor kan der opstå det problem, at man med anden traditionsbaggrund kan ønske sig eksamensbeviser, credits, hvilket dog ikke nødvendigvis invaliderer den afgørende målsætning: at skabe selvstændigt tænkende, indsigtsfulde borgere. Dette allerede i forhold til tysk tradition, hvor Grundtvig registrerede kulde og livløshed. Hans jævne og virksomme liv på jord forudsatte et kristent element. Også begrebet om det talte ord fremdrages, og værdsættelsen af det kvindelige, forstået som en universel kategori (og altså ikke som en "feministisk"). Begrænsende i forhold til andre lande er derimod nok hypostaseringen af, at det danske folk skulle være det moderne udvalgte folk, forsynet med en særlig, velskabt næstekærlighed. $^{5}$

\section{Overscettelsesproblemer}

Et af Werner Görnandt udgivet hæfte med oversættelser til tysk af grundtvigske salmer giver L. L. Albertsen anledning til nogle principbetragtninger i GrSt 1970. Teksterne - oversat efter versionerne i Den Danske Salmebog - løsgør sig i processen fra den litteraturhistoriske tilblivelsessituation, herunder forbindelsen med samtidens verdslige sang, og føjer sig ind i en tysk tradition, både hvad angår form og ind-

5 I GrSt 1999 behandler Jens Holger Schjørring "den nationale Grundtvig" og hans Tysklandsbillede(r), samt virkningshistorien i Tyskland efter grænsefikseringen i 1920. Et "tilsyneladende permanent had til alt tysk" forliges ikke ret vel med tankerne om "folkelig frihed og national ukrænkelighed", men Schjørring gør gældende, at Grundtvig ikke i det centrale anliggende var styret af "nationalistisk snæversyn eller hævntørst". At i vore dage forestille sig en tysk folkekirke uden om de nazistiske erfaringer lader sig næppe gøre, og slet ikke uden et substantieret indtryk af Grundtvigs tænkning. 
hold. Strukturforskelle sprogene imellem fremtvinger ændringer, billedsproget banaliseres, "nye" stiltræk fra ældre tysk salmedigtning importeres, fortolkende omskrivninger søger mod allegorien, osv.

S. A. J. Bradley redegør i "Hvilken Oversættelse! Hvilket Galskab!" (GrSt 2000) for det problematiske i, at Grundtvig knap nok er tilgængelig i engelsk oversættelse, men også for vanskelighederne - de almindelige såvel som de Grundtvig-specifikke - ved at råde bod på miseren. Digteren kendte meget vel til problemerne, titlens udbrud er fra G. J. Thorkelins bemærkninger til hans egen Beowulf-gendigtning, som Bradley diskuterer, ligeledes i GrSt 2000 ("Det er hvad jeg kalder at oversætte Digte. Grundtvig as translator"). ${ }^{6}$ Her gælder det "Bradley as translator", for så vidt som fire salmeoversættelser af egen avl illustrerer pointerne. Nye oversættelser af allerede oversatte salmer er fornødne af den enkle grund, at brugssituationen frem for hensynet til den poetiske kraft "skabte" dem. Ofte er de gjort sentimentale og pietistisk sødladne. Omskrivning og forkortelse forekommer, samt selvfølgelig misforståelser og egentlig uformåenhed af sproglig eller poetisk art. Ord-for-ord-oversættelse giver menings- og åndløse resultater. Men hvordan redder man både meningen og ånden? Vanskelighederne er talrige, nogle ligger i sprogstrukturerne, andre i ordforrådets konnotationsspektre, og atter andre i de poetiske konventioner. Endelig kan der forekomme intertekstuelle referencer eller referencer til forhold helt uden for sproget. ${ }^{7}$

\section{Grundtvig i Norden}

Peter M. Rasmussen beretter i GrSt 1989-1990 om "Den grundtvigske arv på Færøerne". Som bekendt var Svend Grundtvig den første, der lancerede tanken om, at færøsk burde erstatte koloniherresproget dansk. ${ }^{8}$ Den blev i 1889 udmøntet i et foreningsprogram til sprogets genrejsning og etableringen af en folkehøjskole. Modersmålet blev altså det centrale element $\mathrm{i}$ den nationale identitetsdannelse. I Rigsdagen talte Grundtvig for, at færingerne skulle bevare deres ejendommelighed og selv - i deres egen forsamling - afgøre, hvilke love der skulle gælde for dem. På linje med selvstyrehøvdingen Jóannes Patursson, men modsat historikeren H. J. Debes, opfatter Rasmussen dette

\section{Jf. GrSt 2009, 46.}

Hvordan formidles f.eks. Grundtvig-salmernes udtryk for stemningen omkring solnedgang, når nu engelske landsbykirker ikke ringer solen ned?

8 Skriftet Dansken paa Færøerne, 1845, foranlediget af Roskilde Stænderforsamlings udmelding om, at færøsk var et ikke-sprog. Udmeldingen fik Grundtvig sen. til at protestere og skrive "Færinge-Saga" - og V. U. Hammershaimb til at gøre gældende, at det ikke kunne være rigtigt med magtbud "at udrydde et saa dyrebart og helligt Klenodie som Modersmaalet". 
som et "konkret indlæg for færingernes selvbestemmelsesret", ligesom han fremhæver, at Grundtvig i fortsættelsen fik stor indflydelse på den nationale bevægelse, der inkluderede læseforeninger, ordbogsarbejde, kvadindsamling, højskoleophold i Danmark, osv. I årene frem mod oprettelsen i 1899 af den færøske grundtvigske højskole på Fagralid blev der ydet støtte til godt 200 højskoleophold.

Valdemar Nielsens artikel "Grundtvig set fra Sverige" i GrSt 1958 peger indledningsvis på Geijers optagethed af Grundtvigs fremstilling af den nordiske mytologi. Mere forbeholden var Tegnér, der i et brev kaldte Grundtvig "ett geni som förlorat forståndet". Lorenzo Hammarsköld lod sig fascinere af Verdenskrøniken, men tager til genmæle mod de ringe tanker dér om svenskerne. P. Wieselgren indfanges af tanken om Nordens videnskabelige forening og forsøger at lokke Grundtvig til Lund ved domkirkens 700-års jubilæum, men Grundtvig ville ikke nogen kirkelig forening og tog forbehold over for skandinavismen. Han spillede dog en betydelig rolle i forbindelse med de nordiske kirkemøder, uden at de svenske delegater kom til dyb forståelse. I anden sammenhæng blev Fredrika Bremer betaget af Grundtvig, og O. P. Sturzen-Becker leverede en formelig eulogi over ham, den "ärevördiga hvitlockige gubben", som man må formode "formligen bivuakerer bland sina böcker och pergamenter". Efter læsning af en artikel af Otto Borchsenius om, at det var på tide at tilbageerobre Grundtvig fra grundtvigianerne "for den almindelige danske litteratur", skrev Victor Rydberg, at han opfattede ham som "en Cædmon i vårt århundrade". De svenske folkehøjskolefolk hævdede deres uafhængighed af Grundtvig, men anerkendte ham dog som foregangsmand og vedgik inspirationen, f.eks. ved at rejse ham en mindesten på Skamling på 40-årsdagen for talen dér. Man sporer en vis uenighed i Sverige om og i hvor høj grad højskolen derovre er grundtvigsk. Svensk teologis beskæftigelse med Grundtvig er ikke omfattende. Man beflittede sig på med Martensen'sk ammunition at dæmme op for det grundtvigske "sværmeri". Førende kirkefolk som Nathan Söderblom fik sent øje på Grundtvig, men nåede at få ham indplaceret $i$ "raden av alla tiders profeter". Andre sammenlignede ham med Luther og Augustin - eller de sammenlignede hans salmedigtning med Wallins, der f.eks. ser døden som ven, hvor Grundtvig ser den som fjende. I øvrigt er Grundtvigrepræsentationen i den svenske salmebog ubetydelig. En række liv-ogvirke-skildringer fremhæver hans tanker om "Nordens pånyttfödelse och kristendomens återuppståndelse". En skribent opfatter grundtvigianismen som en komplettering af svensk kristendoms pietisme. En del vand er naturligvis løbet til havs siden fremkomsten af denne meget læseværdige artikel. 
Valdemar Nielsen lod den i GrSt 1961 få følgeskab af "Svensk folkehøjskole og Grundtvig", et bidrag, der spinder videre på trangen til at forklejne indflydelsen fra Danmark. Det var i forsøget på efter 1864-nederlaget at holde liv i den skandinaviske bevægelse, at Aug. Sohlman tog en række initiativer, der resulterede i oprettelsen af en højskole ved Vättern. Kontakter over Sundet var der rigtignok, men de vedrørte mest den praktiske udformning. Højskolen skulle ikke blive "en främmande planta i svensk jord". Forskellen blev lejlighedsvis begrundet i nationalkaraktererne. Almindelige danskere har en "hos oss okänd lätthet" til mundtlig formulering, som måske havde bevæget Grundtvig for langt ad mundtlighedens vej i sin kritik af den lærde skole. En lærebog var ikke at foragte! Og måske var det danske sigte politisk-agitatorisk? Fortsatte kontakter blødte efterhånden, især efter det nordiske højskolemøde på Testrup i jubelåret 1883, mistænksomheden op, specielt takket være Leonard Holmström, det svenske sidestykke til Ludvig Schrøder. Om "det levende ord" nåede man ikke til fuld enighed - ordet kan begejstre, men også forføre (og trætte, som det engang blev tilføjet); måske forbandt svenskerne det mere med "tale" end med "samtale". Ved en bestemt lejlighed blev trosbekendelsen (med tvivlsom ret) tilskrevet den danske højskole, hvor sandhedssøgen à la Rydberg blev tilskrevet den svenske. Åndelige værdier er immervæk helt afgørende, også om den svenske højskole er mere kundskabsorienteret end den danske. Grundtvig kunne derom have ytret: "Vi må huske, at de er svenske, og kan ikke tage det helt på samme måde som vi." $"$

Grundtvig i finsk perspektiv er emnet for en artikel af Gustav Björkstrand i GrSt 1999. I Grundtvigs egen bevidsthed blev der kun plads til tre nordiske riger. Til gengæld tog Finland med ildhu imod folkehøjskoletanken og oprettede fra 1889 og frem 91 skoler, de fleste grundtvigske - modsat svenskerne fandt man intet at indvende mod den klassifikation. Pionererne besøgte flittigt de danske folkehøjskoler. I et skrift fra 1944 trak en fremtrædende finsk højskoleforstander

9 Emnet "Grundtvigs forhold til Sverige" diskuteres også i et Valdemar Nielsen-foredrag trykt i GrSt 1970. I forbindelse med det svenske tronfølgervalg fandt Grundtvig Nordens forening ønskelig under Frederik VI, men valget faldt jo på Bernadotte, der skuffede ham ved at forhandle med stormagterne om at besætte Norge. Som før nævnt fik Grundtvig senere kontakt med Wieselgren, der kommenterede skriftet om den videnskabelige (ikke politiske eller kirkelige) forening og inviterede ham med til de skandinaviske kirkemøder. Det i Lund 1859 kom han ikke til, måske fordi teologerne dér var imod hans "sværmeri". Resten er gentagelse. Nielsen kan pointere, at stedet, hvor han taler, Nordens folkliga Akademi i Kungälv, er en sen frugt af Grundtvigs tanker. 
ligefrem en parallel til pilgrimmenes rejser til det hellige land. Skolerne gav kristendomsundervisning og tilgodeså også praktiske fag, og de lod Kalevala få den nordiske mytologis plads. I mellemkrigsårene tog vækkelsesbevægelserne initiativ til en række Kold'sk orienterede skoler. På salmeområdet dukkede Grundtvig først op i 1922; nu er der ni salmer af ham i den svenske og seks i den finske salmebog. Egentlig Grundtvig-forskning er det ikke blevet til, undtagen netop på højskoleområdet, som belyses i et par disputatser.

\section{Grundtvig i Europa}

Receptionen af den grundtvigske folkehøjskole i tysk voksenuddannelse er emnet for et bidrag af Norbert Vogel i GrSt 1989-1990. Generelt gælder, at receptionen ofte er korrumperet, specielt hvad angår frihedsaspektet i Grundtvigs pædagogiske tænkning. I perioden før 1920 bevægede receptionen sig fra tøven og forbehold på grund af de politiske spændinger og Grundtvigs antityske markeringer til distant interesse for højskoletankerne, dels som led i den udbredte reaktion mod den urbane industriudvikling, men dels også som muligt middel til løsning af sociale problemer og til befordring af landbrugets økonomiske udvikling. I Weimar-tiden kerede man sig kun lidt om højskoletankernes frihedsimpuls, under nazismen var den slags jo slet ikke gangbart, og $\mathrm{i}$ årtierne efter har det nok skadet Grundtvigtilegnelsen, at visse højskolerelevante begreber havde fået en bismag. Der blev ellers lagt en solid bund for receptionen i starten af 1900tallet. G. Rønberg Madsen og F. Wartenweiler udgav pædagogiske disputatser, ${ }^{10}$ og A. H. Hollmann skildrede højskolens betydning for udviklingen af folkekulturen i Danmark i en bog, der fik europæisk udbredelse. Imidlertid måtte den danske model konkurrere med englændernes for University Extension. Samfundsnyttig videreuddannelse forekom ofte mere attraktiv end enkeltindividets dannelse. Der var trods alt i Weimar-tiden uddannelsesteoretikere, der (som Erich Weniger) gerne så Grundtvigs højskoleideer lagt til grund for en "moderne folkedannelseslære", men generelt gik der en kløft mellem tidens elitære meningsdannere på alle det åndelige livs områder og det praktisk-politiske arbejde, som bidrager til forklaringen af interesseløsheden. Den tidlige nationalsocialisme kunne i svage øjeblikke opfatte Grundtvig som en tilforladelig allieret. Hans 150-årsdag gav en taler lejlighed til at takke Hitler og Hindenburg for harmonisk samarbejde, der kunne danne basis for, at den tyske folkehøjskole blev, hvad Grundtvig havde

10 K. E. Bugge har venligt gjort mig opmærksom på, at disse to disputatser (fra 1905 og 1913) er ældre end den, som jeg i Del I, note 4, kalder "den allerførste Grundtvig-disputats". 
forestillet sig, "nämlich zu einer Pflegestätte des Volkstums auf christlich-germanischer Grundlage". Udfordringen på den bane var jo så at ophæve diskrepansen mellem Grundtvigs foregribelse af Germanentum og hans undsigelse af tysk anmasselse. En strategi gik ud på at betone, hvad man kunne lære af Grundtvig, for eksempel "dass wir auf gutem Wege sind", mens de slatne grundtvigianere står for forfladigelsen. Disse sidste forstod Grunḍtvig dårligere end nazisterne og havde gjort ham til en art skytshelgen for det liberale demokrati! Mere resolutte folk skar igennem og erklærede Grundtvigs udgrænsning af dansk folkelighed fra det germanske fællesskab og leflen for engelsk frihedstænkning for uforenelig med nationalsocialistisk ideologi. Begrebet "Volkheit" var hermed bragt i sammenhæng med Blut-undBoden-tankegangen og hvad dertil hørte! ${ }^{11}$

Emnet for Götz Harbsmeiers bidrag til 100-årsseminaret i 1972 var "Grundtvig and Germany" (GrSt 1973). Efter Anden Verdenskrig figurerede han i den almindelige bevidsthed som en art forløber for den nazistiske racetænkning. En mand uden for indflydelse, altså, så Harbsmeier talte i stedet for om, hvilken rolle han burde spille. Hvor tysk protestantisk teologi, specielt barthianerne, taler ud fra Gud, lader Grundtvig gudsinspirationen åbenbare sig - sandt, kærligt, kraftigt - i det levende ord. Også hvad angår f.eks. skriftens autoritet og menneskets medfødte fordømthed, burde Grundtvig udgøre en udfordring.

På tilsvarende vis overvejer G. F. W. Herngreen i GrSt 1976, hvad Grundtvig "i dag" kunne betyde for nederlandsk reformert teologi, hvor han er tilnærmelsesvis ukendt eller kun kendt fra Kierkegaards domfældelse. Den "mageløse opdagelse" har aldrig anfægtet nederlandske bibelfortolkere, endsige f.eks. Karl Barth. ${ }^{12}$ Et par salmer optaget $\mathrm{i}$ den nederlandske salmebog har imidlertid skabt spirende interesse. Reformerte teologer må forstå, at Gud ikke "tilskriver" os troen, men at fokuseringen på "det levende ord" på den anden side ikke gør Bibelen værdiløs. Herngreen tilretteviser i øvrigt Grundtvig, hvad angår den kalvinske nadverlære; også dér drejer det sig om Guds handlen og Kristi virksomme nærværelse. Ganske vist er Gud på suveræn vis fri, men han er aldrig vilkårlig, tværtom trofast og til at regne med som netop Barth har udredt det. Miskendelsen af Grundtvig vedrører især hans høje vurdering af trosbekendelsen. Den reformerte menighed

11 Jf. Norbert Vogels "Habilitationsschrift" Grundtvigs Bedeutung für die deutsche Erwachsenenbildung, Bad Heilbrunn 1994, 336 s.; anmeldt af Jens Holger Schjørring i GrSt 1997.

12 Barth burde ifølge Herngreen have været mere lydhør over for Grundtvig, fordi begge trods oplagte forskelle jo søger bagom skriften til "den levende Herre selv". Han kunne have ladet sig inspirere af Regin Prenters bidrag til det festskrift, man gav ham i 1936. 
har svært ved at forstå, at dåbshenvendelsen sker til barnet, men pointen er jo, at "ordet" forstås som personlig kaldelse frem for som ortodoks sandhedsfremsigelse.

\section{Grundtvig i Amerika}

Thorvald Hansen pointerer i artiklen "Grundtvigianism and Danes in America" (GrSt 1998), at etableringen i 1871 af en dansk kirke i USA skete i en betændt atmosfære, idet den et par årtier ældre norsk-danske kirke, oprindelig præget af W. A. Wexels' Grundtvig-inspirerede lære, i takt med udviklingen i Norge var blevet ramt af "GrundtvigianerSkræk". Da danskerne i den norsk-danske kirke selvstændiggjorde sig som Det danske evangelisk-lutherske Kirkesamfund, blev det som biblicistisk alternativ til den liberalt favnende danske kirke. Denne fik præsteseminarium i Grand View, dog først i 1897, mens alternativet baserede sig i Blair på det nuværende Dana College. Inden for den danske kirke opstod der flere konflikter, især omkring Frederik Lange Grundtvig. Han opponerede voldsomt mod hemmelige broderskaber inden for kirken. Han var med til at etablere Dansk Folkesamfund, der skulle holde dansk sprog og kultur i hævd, men blev mistænkt for at ville konkurrere med kirken. Voldsomst gik det til i 1893-94, da en ny kirkeforfatning resulterede i en splittelse, så der pludselig var tre danske kirker - frem til 1896, hvor udbryderne fusionerede med Blair-folkene.

Grand View College udviklede sig hurtigt fra præsteseminarium til flerstrenget uddannelsesinstitution og holdt ubesværet Grundtvigarven i hævd til midt i 1950'erne, hvorefter den af forskellige grunde, blandt andet forskydninger i rekrutteringsgrundlaget, blev presset. Mark C. Mattes rapporterer i "Reclaiming Grundtvig for Grand View College" (GrSt 2007) om en række initiativer, der skal sikre institutionens fortsatte eksistens på modernitetens betingelser uden at sætte arven over styr.

Sangskattens forvaltning blandt dansk-amerikanske immigranter har identitetsopretholdende effekt, pointerer Marianne Stølen i "Om Grundtvigs sanges liv i Nordamerika" (GrSt 2008). F. L. Grundtvigs store indsats for dansk menighedsliv i USA omfattede blandt andet udgivelse i 1888 af Sangbog for det danske Folk i Amerika, hvor nogle af Grundtvig-numrene var skåret til med henblik på immigranternes brug af dem. Grundtvigs salmer og sange, i alt 130 i 1949-udgaven, inspirerede præsten S. D. Rodholm og andre til oversættelsesaktivitet såvel som til produktion af nye salmer og sange, som i mellemkrigstiden indgik i engelsksprogede salmebøger henvendt til danskamerikanerne $\mathrm{i}$ anden og tredje generation. Som sidste skud på traditionen udkom i 1974 en samling favorites fra en af disse, med 91 num- 
re, af hvilke seks skyldes Grundtvig; det er den, som identitetsopretholdelsen i dag beror på. ${ }^{13}$

I Stølens bagage mangler Enok Mortensens "Den danske salme i Amerika" (GrSt 1974), der er snævrere i sigtet, men eksemplificerer bredere. Artiklen oplyser, at Mormonkirken midt i 1800-tallet havde tag i $75 \%$ af de danske indvandrere, og at $19 \%$ af dem slog sig ned $i$ Utah. Deres danske salmer kunne være tendentiøst tillempede. I "Den signede Dag" står der for eksempel: "Og yndeligt de sig herligt sno / Om Joseph og Hyrums Minde". Foruden Rodholm fremhæves også J. C. Aaberg og P. C. Paulsen som oversættere. De slap knap nok ind i lutherkirkernes fællessalmebog fra 1958, A World of Song.

\section{Grundtvig i Asien og Afrika}

Mesteparten af, hvad der i øvrigt er fremkommet i årbogen om Grundtvigs betydning ude i verden, omhandler pædagogik og uddannelse. Asoke Bhattacharya og Tandra Matra, "People's Education in India" (GrSt 1998), diskuterer mulighederne for at lade grundtvigske folkehøjskoletanker inspirere indisk voksenundervisning inden for rammerne af et projekt, der på sigt skal komme analfabetismen til livs. ${ }^{14}$

Hanne Luplau Hansen redegør i GrSt 2003 for konkrete klasserumsdialoger og -refleksioner i en sydøstasiatisk efteruddannelsessammenhæng, hvor Grundtvigs pædagogiske ideer (reduceret til nøglebegreber) blev inddraget "to broaden the scope". Ikke overraskende blev konklusionen, at ideerne bør kunne overføres til tredjeverdenslande - til inspiration.

Lilian Zøllner skildrer i GrSt 1994 et projekt, der skulle føre til etablering af en grundtvigsk højskole i Filippinerne. Den histories helt er den katolske præst Edicio de la Torre, der som tak for sit engagement i socialt reformarbejde blev fængslet af Marcos-regimet. Efter demokrati-indførelsen fra oven blev det vigtigt at give folket medejerskab til landets ledelse - hvilket ledelsen reelt ikke havde interesse i; dens mål var et elitært styre eller et demokratur, hvor folket så forventedes at føle ansvarlighed over for etablissementet. Under ophold i Danmark modnedes tanken om en dansk-finansieret filippinsk

${ }^{13}$ For ganske nylig udkom Marianne Stølen, The Story of 'Den Røde' - A Danish-American Songbook. A Century of Identity Formation in Songbook use, 2010, $345 \mathrm{~s}$.

14 Asoke Bhattacharya udgav i 2008 en bog om folkelig uddannelse hos Grundtvig, Tagore, Gandhi og Freire, jf. anmeldelse af Vagn Wåhlin og Kim Arne Pedersen i GrSt 2008, blandt andet med betoning af, at Gandhi nok snarere udgør en symbolsk værdi end en realistisk vision. Grundtvig-afsnittet er også fremkommet i GrSt 2005 ("N. F. S. Grundtvig. Educationist extraordinary"). 
højskole til forøgelse af levestandarden, den sociale mobilitet og det lokale demokrati. Projektet måtte konfrontere frygtindgydende udfordringer: befolkningen kæmpede med fattigdom, var demoraliseret og initiativforladt, følte sig magtesløs og underlegen, længtes efter stærke ledere, osv. Lilian Zøllner redegør for indholdet af det første kursus (oktober 1992), samt for de indtryk, den i øvrigt mobile skoles lærere modtog under besøg på danske højskoler.

Stig Thøgersen beskæftiger sig med Grundtvig i Kina (GrSt 1995). Introduceret i $1909 \mathrm{kom}$ han til at spille en rolle $\mathrm{i}$ forestillingen om at overkomme national ydmygelse gennem undervisning. Gennembruddet skete o. $1930 \mathrm{i}$ forbindelse med, at man fik øje på landsbyernes potentiale. Den "danske model" burde kunne befordre den fornødne forandring uden revolutionær ændring af ejendomsforholdene, men dog drevet frem af bøndernes aktive interesse. Mange artikler så dagens lys, et par bøger blev oversat - og i debatten tonede Grundtvigs fædreland frem som "et fjernt, lykkeligt Utopia": Dette "sumpede, magre, kolde Danmark, hvor de året igennem knap ser solens lys", havde formået det; hvis Kina gjorde det kunsten efter, måtte det dobbelte resultat kunne nås med den halve indsats. I Zouping-distriktet blev den af konfucianismen inspirerede kulturfilosof Liang Shuming sat i spidsen for et projekt til landområdernes genopbygning. Han fik kontakt med og besøg af Peter Manniche, og han etablerede landsby- og distriktskoler, der også skulle være politiske og kulturelle centre - i det hele taget være "de levende celler, som Liangs ny-traditionelle Kina blev bygget af". Men succesen var begrænset. Da rekrutteringen til voksenundervisningen voldte problemer, opgav man frivillighedsprincippet. Og trods stor skepsis over for indblanding ovenfra kom bevægelsen i realiteten til "at fungere som den moderniserende stats forlængede arm ud i landområderne". I øvrigt tog den japanske invasion i 1937 livet af projektet. Først med kommunismen kom det til en omfattende befolkningsmobilisering funderet i national vækkelse og social omvæltning. Men nu med Mao som den store rorgænger. ${ }^{15}$

\section{Jubilæer og konferencer}

"A Century after Grundtvig" var overskriften for et internationalt seminar holdt i Helsingør i august 1972. En del af foredragene fremkom i GrSt 1973, med fyldig opsummering på dansk ved William Michelsen. Kaj Thaning holdt indledningsforedraget, der konkluderede, at det grundtvigske menneskesyn stadig kunne inspirere til opgør med mo-

15 I GrSt 2007 bringes - med en indledende kommentar af A. M. Allchin et bidrag af Wen Ge, der relaterer Grundtvigs eskatologi til nutidig teologi såvel som til "kinesisk forståelse af skabelse og genløsning". 
dernitetens indsnævrende livsforklaring. Mennesket er fortsat "et guddommeligt eksperiment af støv og ånd”. Også Regin Prenter aktualiserede Grundtvig, men med fokus specielt på hans teologi. Folkehøjskolen blev på tilsvarende vis behandlet med henblik på både dens opståen og vækst og dens rolle og virksomhed "i dag" - i dag måtte den historie nok fortælles anderledes - af hhv. Roar Skovmand og Thomas Rørdam.

200-året for Grundtvigs død blev markeret i GrSt 1983 med en oversigtsartikel, "Sin samtids kritiker", af William Michelsen. At den oprindelig er skrevet med henblik på et internationalt publikum forklarer det nøjeregnende præg, men er på den anden side en styrke. En "elementær" fremstilling funderet på en imponerende indsigt og et suverænt overblik.

Bidragene til en konference med titlen "National Identity - International Community" i Århus 1992 fremkom i GrSt 1993. A. M. Allchin pointerede indledningsvis, at begrebet om national identitet hos Grundtvig ikke var "nationalistisk", men indebar en samtidig forståelse af sig selv som dansk og af landets plads i universalhistorien. Ganske vist førte Grundtvig sig lejlighedsvis polemisk frem som "nationalist" - som indledningsvis nævnt i den følgende artikel af Lorenz Rerup om Grundtvigs folkelighedsbegreb og 1800-talsnationalismens fremkomst. Herders forestilling om "den jævne mand" som folkeåndens bærer forskød sig hos de nationalliberale under indtryk af Fichtes idealisme i retning af, at det blev den (ud)dannede elite, som skulle bære. Blandt de danske i Slesvig blev den "emanciperende" nationalisme, blandt andet under Grundtvigs indflydelse, fastholdt, og den udbredte sig siden gennem højskolebevægelsen. Rerup påpeger, at denne ikke-undertrykkende nationalisme bør kunne tjene som forbillede for eksempel i forhold til europæiske mindretal.

Netop om den art forhold drejer de følgende indlæg sig. Bedwyr L. Jones orienterer om det walisiske sprog som identitetsbærende. Fortrængningen af sproget i kølvandet efter unionsloven af 1536 synes at være gået i stå, uden at Grundtvigs tanker har spillet nogen rolle.

Et par af bidragene har fokus på forhold i Balticum. Med afsæt i de grundtvigske folkelighedstanker pointerer Hans Henningsen, at landene dér kan gælde som eksempler på nationalstater, der i modsætning til "et supranationalt demokrati" har mulighed for at udvikle sig til egentlige, folkelige demokratier. Og med samme afsæt konstaterer Holger Bernt Hansen, at tredjeverdenslandene gennemgående er blevet mødt med koloniseringspolitik og missionsfremfærd, så man vanskeligt kan mobilisere optimisme over for de forsøg på omplantning af 
tankerne, som faktisk forekommer. Kachi Ozumba fra en nigeriansk skole opkaldt efter Grundtvig skildrer et sådant forsøg. ${ }^{16}$

Et seminar (en consultation) om Grundtvig og den engelsktalende verden, afholdt i Chicago i 1995 og kort omtalt af Jakob Balling i GrSt 1996, resulterede i en særlig publikation: Heritage and Prophecy. Et par af foredragene kan dog læses netop i GrSt 1996.

I 1999 blev der under ledelse af Asoke Bhattacharya indledt en række Grundtvig-konferencer på Jadavpur-universitetet i Calcutta. K. E. Bugge har i GrSt 2000 rapporteret om denne første konference, hvori adskillige danske forskere deltog. Fra indisk side opfattes Grundtvig især som en uddannelsestænker, hvis ideer kan tilpasses, men ikke overføres. Holger Bernt Hansen gjorde opmærksom på, at tredjeverdenslandene prioriterer de forskellige undervisningsformål anderledes, end vi gør, hvilket "bringer en skævhed ind i ulandenes forventninger til den danske folkehøjskoles ide". - Konferencen i 2003, åbnet samtidig med indvielsen af et Grundtvig-forskningscenter på Jadavpur, foretog en sammenligning mellem de to digterfilosoffer Grundtvig og Rabindranath Tagore, jf. S. A. J. Bradleys rapport i GrSt 2003. De indiske bidragydere talte varmt om Tagore, men turde dog ikke tage ham som udtryk for "a definitive figure of Indianness". Bradley betegnede de to mænd som "similarly problematical cultural icons in an increasingly globalised world". - Konferencen i 2007 varede længere og sigtede bredere end de foregående, således som det fremgår af Bhattacharyas rapport i GrSt 2007. Ti temaer var på agendaen, og et dusin danske forskere var blandt deltagerne.

For en overordnet betragtning gælder, at mange af bidragene genereret $\mathrm{i}$ forbindelse med konferencer og seminarer, hvor pædagoger og forskere har orienteret hinanden og kastet lys over problemet med at omplante en danskhedsforankret tænkning til alverdens lande, støder på et "oversættelsesproblem". Danskhed kan ikke eksporteres og overtages, højst danne basis for en analog gennemtænkning. Erica Simon har for eksempel diskuteret forholdet mellem, hvad Grundtvig kalder folkelighed, og hvad Leopold Senghor kalder négritude (GrSt 1973). Samtidig med, at mange lande i den tredje verden søger national og kulturel identitet, breder "en global superkultur" sig forskelsudslet-

16 Et bidrag af Inge Adriansen om danske og tyske nationalsymboler peger frem mod en artikel i GrSt 2006. Hvor de tyske symboler præges af voldsom udfoldelse, behersker svagheden de danske, "i overensstemmelse med Grundtvigs bestemmelse af danskheden som kvindelig". Theodor Jørgensen skitserer Grundtvigs had til tysk magthævdelse vis-a-vis dansk blødhed som baggrund for en omtale af det oversættelsesarbejde, som der blev taget initiativ til i 1985, og som først nu nærmer sig en afslutning med en udgivelse på op mod 1000 tryksider i efteråret 2010. 
tende hen over alle grænser. Hvor Grundtvig ville vække til levende vekselvirkning "mellem Digterne og Folket", taler det nye Afrikas intellektuelle om, at folket må "genvinde sin elite". Således også i négritude-bevægelsen, uanset, at den måske hos Grundtvig kan finde stof til eftertanke. ${ }^{17}$

17 Simons artikel "Grundtvig et la France" (GrSt 1969) har idéhistorisk sigte og burde have været omtalt i Del I. Efter en forbigående ungdomsfascination af fransk ånd blæste Grundtvig til kamp mod 1700-tals-rationalismen (deisme, ateisme, osv.). Dens "Hundeklogskab" oplyste overfladen uden at begribe, at "menneskets gåde nødvendigvis må være hyllet i dunkelhed". Ikke desto mindre har folkeligheden grobund i Frankrig. Normannerne nærede de franskes latinitetsmodstand, båndet til pavedømmet løsnedes dér før reformationen, der jo endda gav kirkelatinen asyl i skolen, osv. Egentlig "tilgivelse" af oplysningstiden glimter frem et par steder i utrykt materiale. 


\section{Personregister}

En parentes med et $\mathrm{N}$ efterfulgt af årstal, for eksempel (N2002), markerer, at der henvises til en nekrolog over vedkommende i den pågældende årgang af Grundtvig-Studier.

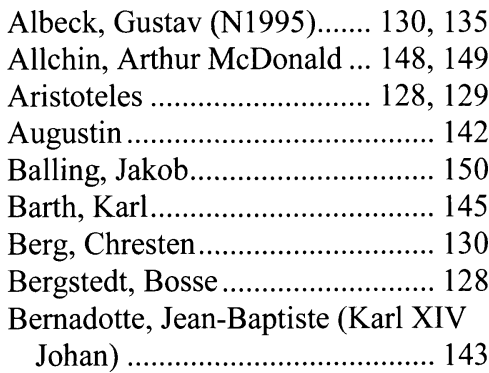

Bhattacharya, Asoke............. 147, 150

Birkelund, Regner .........128, 129, 130

Björkstrand, Gustav..................... 143

Bjørnbak, Lars............................ 132

Borchsenius, Otto ......................... 142

Borgbjerg, Frederik .................... 137

Bradley, S. A. J..................... 141, 150

Brandes, Edvard .......................... 137

Bremer, Fredrika ......................... 142

Bugge, Knud Eyvin .......127, 128, 130, 144, 150

Carlsen, Jørgen ............................... 139

Christian VIII ................................ 134

Clausen, Henrik Nicolaj ................ 129

Debes, Hans Jacob.......................... 141

Ehlers, Søren ................................... 138

Eichberg, Henning......................... 136

Estrup, J. B. S............................... 130

Fichte, Johann Gottlieb......... 137, 149

Fink, Troels .................................. 134

Flor, Christian ..................... 132, 135

Foucault, Michel........................... 138

Frederik VI..................................... 143

Freire, Paulo ................................... 147

Gadamer, Hans-Georg.......... 138, 139

Gandhi, Mahatma .......................... 147

Ge, Wen ....................................... 148

Geijer, Erik Gustaf ........................ 142

Goldschmidt, Meïr Aron ...... 137, 138

Grell, Helge (N2000).................... 131

Groh, Martin................................. 138

Grundtvig, Frederik Lange ........... 146

Grundtvig, Svend .......................... 141

Grønbech, Vilhelm ....................... 139

Guldberg, Ove (Høegh-)................ 134

Görnandt, Werner........................... 140

Hammarsköld, Lorenzo ................. 142
Hammershaimb, V. U.................... 141

Hansen, Hanne Luplau................... 147

Hansen, Holger Bernt ........... 149, 150

Hansen, Thorvald .......................... 146

Harbsmeier, Götz (N1979)............ 145

Harms, Claus ................................... 134

Helveg, Fr. .................................... 132

Henningsen, Hans ......... 132, 133, 149

Herder, Johann Gottfried von........ 149

Herngreen, G. F. W....................... 145

Hindenburg, Paul von .................... 144

Hitler, Adolf..................................... 144

Hollmann, Anton Heinrich............. 144

Holmström, Leonard ....................... 143

Høgsbro, Sofus ..................... 132, 133

Ingemann, Bernhard Severin.......... 132

Jones, Bedwyr L. ............................ 149

Jørgensen, Theodor ........................ 150

Kant, Immanuel ............................. 129

Kierkegaard, Søren ........................ 145

Kjær, Holger .................................. 139

Koch, Carl Henrik .................. 129, 130

Koch, Hal.................... 132, 133, 137

Kold, Christen........................ 135, 144

Korsgaard, Ove............. 131, 133, 139

Langballe, Jesper .......................... 137

Ling, Per Henrik ............................ 136

Lorenzen, Peter Hiort..................... 134

Lornsen, Uwe Jens ......................... 134

Lund, Hans........................................ 132

Lundgreen-Nielsen, Flemming ..... 140

Luther, Martin................................. 142

Lyby, Thorkild C. ......... 131, 132, 139

Løgstrup, Knud Eiler ..................... 139

Madsen, Georg Rønberg ................ 144

Madvig, Johan Nicolai .................. 133

Malling, Ove ................................. 134

Manniche, Peter ............................. 148

Mao Zedong................................... 148

Marcos, Ferdinand ......................... 147

Martensen, Hans Lassen ................ 142

Matra, Tandra ................................ 147

Mattes, Mark C............................. 146

Michelsen, William (N2002) 148, 149

Mortensen, Enok............................. 147

Møller, Jes Fabricius...................... 138

Nielsen, Niels Kayser ..................... 136 
Nielsen, Rasmus ............................. 130

Nielsen, Valdemar (N1973).. 142, 143

Nissen, Gunhild ........................... 132

Ozumba, Kachi .............................. 150

Patursson, Jóannes .......................... 141

Paulsen, P. C.................................. 147

Platon.................................. 128, 129

Prenter, Regin (N1991)......... 145, 149

Pringel, Victorin ............................. 130

Rasmussen, Peter M....................... 141

Rerup, Lorenz .................................. 149

Rodholm, S. D. ................... 146, 147

Rydberg, Victor ................... 142, 143

Rørdam, Thomas............................. 149

Schjørring, Jens Holger. 129, 140, 145

Schrøder, Ludvig .................. 133, 143

Senghor, Leopold........................... 150

Shuming, Liang ............................. 148

Simon, Erica (N1993) .................... 150

Skovmand, Roar ........................... 149

Sohlman, August............................ 143

Stougaard, Jens ............................ 128

Struensee, Johann Friedrich ........... 134

Sturzen-Becker, Oscar Patric ......... 142
Stølen, Marianne ....................146, 147

Söderblom, Nathan ........................ 142

Tagore, Rabindranath .............147, 150

Tegnér, Esaias ............................... 142

Thaning, Kaj (N1994) ...137, 139, 148

Thorkelin, Grímur Jónsson............ 141

Thyssen, A. Pontoppidan (N2004) $127,128,134$

Thøgersen, Stig ........................... 148

Tjørnehøj, Henning ...................... 137

Torre, Editio de la.......................... 147

Trier, Ernst …................................ 133

Vind, Ole...............................131, 137

Vogel, Norbert........................144, 145

Wallin, Johan Olof ........................ 142

Walsted, Pål Henning Bødtker ..... 133

Wartenweiler, Fritz........................ 144

Weniger, Erich .............................. 144

Wexels, Wilhelm A....................... 146

Wieselgren, Peter ..................142, 143

Wigh-Poulsen, Henrik ................... 138

Wåhlin, Vagn (N2009).. 135, 136, 147

Zøllner, Lilian ......................147, 148

Ørsted, Hans Christian .................. 130 